\title{
Model mass spectrometric study of competitive interactions of antimicrobial bisquaternary ammonium drugs and aspirin with membrane phospholipids
}

\author{
V. A. Pashynska', M. V. Kosevich ${ }^{1}$, A. Gomory ${ }^{2}$, K. Vekey ${ }^{2}$ \\ ${ }^{1}$ B. I. Verkin Institute for Low Temperature Physics and Engineering, NAS of Ukraine \\ 47, Lenin Ave., Kharkov, Ukraine, 61103 \\ ${ }^{2}$ Institute of Organic Chemistry of Research Centre for Natural Sciences of the Hungarian Academy of Sciences \\ 59-67, Pusztaszeri Str., Budapest, H-1025, Hungary \\ vlada@vl.kharkov.ua
}

\begin{abstract}
Aim. The aim of the study is to reveal molecular mechanisms of possible activity modulation of antimicrobial bisquaternary ammonium compounds (BQAC) and aspirin (ASP) through noncovalent competitive complexation under their combined introduction into the model systems with membrane phospholipids. Methods. Binary and triple systems containing either decamethoxinum or ethonium, or thionium and aspirin, as well as dipalmitoylphosphatidylcholine (DPPC) have been investigated by electrospray ionization mass spectrometry. Results. Basing on the analysis of associates recorded in the mass spectra, the types of nonocovalent complexes formed in the systems studied were determined and the supposed role of the complexation in the BQAC and ASP activity modulation was discussed. The formation of associates of BQAC dications with ASP anion is considered as one of the possible ways of deactivation of ionic forms of the medications. The formation of stable complexes of BQAC with DPPC and ASP with DPPC in binary systems as well as the complexes distribution in triple-components systems BQAC:ASP:DPPC point to the existence of competition between drugs of these two types for the binding to DPPC. Conclusions. The results obtained point to the competitive complexation in the model molecular systems containing the $B Q A C$, aspirin and membrane phospholipids. The observed phenomenon testifies to the possibility of modulating the activity of bisquaternary antimicrobial agents and aspirin under their combined usage, due to the competition between the drugs for binding to the target membrane phospholipid molecules and also due to the formation of stable noncovalent complexes between BQAC and ASP.
\end{abstract}

Keywords: competitive complexation, bisquaternary ammonium compounds, aspirin, membrane phospholipids, mass spectrometry, electrospray ionization.

Introduction. Among urgent biomedical problems, the elucidation of either increase or decrease of the biological activity of several medicines at their combined use is of practical importance in connection with a high probability of mutual modulation of the medications activity in multi-drug therapeutic schemes of the modern medical practice. Along with tests on living organisms, model studies of the mechanisms of action of biologically active compounds at the molecular level permit to save time and resources prior to the experiments with real biological objects. Soft ionization mass spectromet-

(C) Institute of Molecular Biology and Genetics, NAS of Ukraine, 2013 ry as an up-to-date method of molecular biophysics [1] is an efficient tool for studies of biomolecules and their intermolecular interactions [1-4]. Electrospray ionization (ESI) mass spectrometric technique based on spraying solutions of biomolecules in polar solvents is applied to modeling selective noncovalent intermolecular interactions of biologically active agents, medicines in particular, with their specific molecular targets [5-8].

In the framework of a problem of elucidation of molecular mechanisms of action of membranotropic antimicrobial agents we are developing an integrated approach to study of interactions of bisquaternary ammonium compounds (BQAC, $\mathrm{Cat}^{2+} \cdot 2 \mathrm{Cl}^{-}$) with phospholi- 

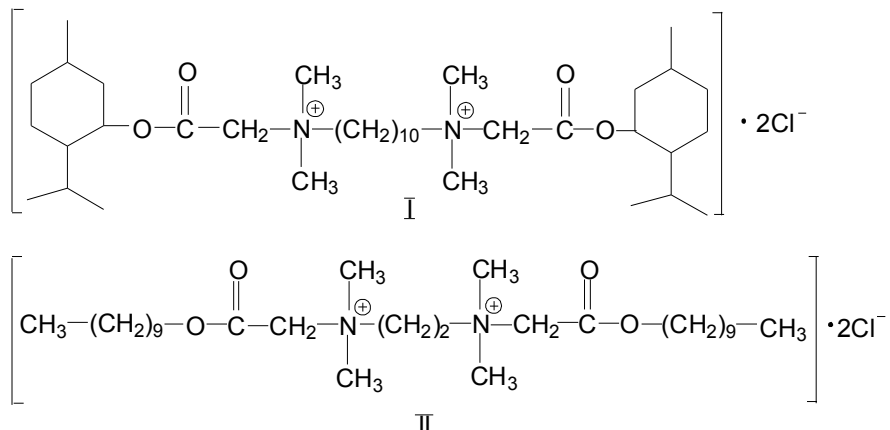

II

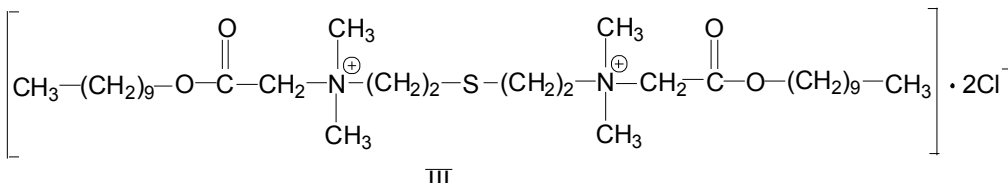

III

Scheme. Structures of the objects of investigation: $I-$ decamethoxinum (monoisotopic molecular mass 692.5 Da); II - ethonium (584.4 Da); III - thionium (644.5 Da); $I V$ - acetylsalicylic acid (180.0 Da); $V$ - dipalmitoylphosphatidylcholine (733.6 Da)

pid assemblies which mimic the membranes of bacterial cells [9-13].

In our previous studies on molecular mechanisms of action of widely used antimicrobial BQACs decamethoxinum and ethonium, a combined application of ESI mass spectrometry, differential scanning calorimetry (DSC), and computer modelling [9] allowed us to reveal the formation of stable supramolecular complexes of the drugs with membrane phospholipids. The formation of such complexes is a prerequisite for the drugs incorporation into membranes, which distorts functioning of bacterial cell and thereby causes either bacteriostatic or bactericidal effect [13].

The background for addressing the above stated problem of investigation of combined action of several membranotropic and biologically active agents by means of mass spectrometry lies in an effect observed by us during characterization of BQACs by matrix-assisted laser desorption/ionization mass spectrometry [14]: substitution of inorganic $\mathrm{Cl}^{-}$counterion of BQAC salts by anions of organic acids, 2,5-dihydrohybenzoic acid (a metabolite of aspirin) in particular, took place in a mixture. Since the formation of stable complexes of the compounds of basic and acidic types can affect and modulate the membranotropic activity of individual drugs [11], the above result stimulated us to expand the study of noncovalent interactions of BQACs with biologically significant organic acids. Among the compounds which can be administered together with BQAC antimicrobial agents for treatment of microbial infections, a popular anti-inflammatory remedy acetylsalicylic acid (aspirin, ASP), which possesses membranotropic properties as well [15], was selected.

In the current investigation different scenarios of possible activity modulation through noncovalent complexation of three antimicrobial BQACs decamethoxinum, ethonium, and thionium with aspirin under their combined mixing with a membrane phospholipid dipalmitoylphosphatidylcholine (DPPC) were examined using ESI mass spectrometry.

Materials and methods. Chemical structures of the objects of investigation are presented in the Scheme. Decamethoxinum (I), ethonium (II) and thionium (III) were synthesized in the Institute of Organic Chemistry of the National Academy of Sciences of Ukraine. Pure acetylsalicylic acid (aspirin) (IV) was obtained from the State Scientific Centre of Medications (Ukraine). Dipalmitoylphosphatidylcholine $(V)$ was purchased from ALSI (Ukraine). Methanol (Super grade), being used as a solvent, was purchased from Reanal (Hungary).

Stock solutions of BQAC, ASP and DPPH ( $5 \mathrm{mM})$ were prepared in a polar solvent methanol and used for 
binary (ASP:DPPH, ASP:BQAC) and triple (ASP: BQAC:DPPC) model systems preparation. Corresponding volumes of the stock solutions were mixed to reach the molar ratio 1:10 of drugs to phospholipid. The mixtures were kept at room temperature for at least $10 \mathrm{~min}$ before the ESI analysis. The spraying procedure required dilution of the solutions to be studied to provide $250 \mu \mathrm{M}$ final concentration of the components. It was proved in numerous studies [5-8] that utilization of methanol as a solvent improves significantly the quality of ESI mass spectra and does not disturb the composition of intermolecular complexes formed in the initial solutions [16].

Mass spectral data were obtained in the positive ion mode, using triple quadruple (QqQ) Micromass Quattro Micro mass spectrometer («Waters», UK) which was equipped with the electrospray ion source. This source was operated in the standard ESI mode [5]. The potential of the spraying capillary was set at $3.5 \mathrm{kV}$. The cone voltage value of $10 \mathrm{~V}$ was used. ESI spectra were recorded in the mass range of 100-2000 Da. Data acquisition and processing were performed using MassLynx 4.1 software («Waters»).

Results and discussion. To reveal the formation of intermolecular complexes of membranotropic drugs and membrane phospholipid DPPH, binary and triple mixtures of the compounds under study were examined by ESI mass spectrometry.

At the initial stage of the study we have tested ASP: DPPH binary mixture with 1:10 molar ratio of the components, whose ESI mass spectrum is presented in Fig. 1. The spectrum contains peaks of the individual components: ASP $\cdot \mathrm{Na}^{+}(m / z 203.1), 2 \mathrm{ASP} \cdot \mathrm{Na}^{+}(m / z 383.2)$ for ASP and DPPC $\cdot \mathrm{H}^{+}\left(m / z\right.$ 734.6), DPPC $\cdot \mathrm{Na}^{+}(m / z$ 756.6), 2DPPC $\cdot \mathrm{Na}^{+}(m / z$ 1491) for DPPH. Note, that cationization by sodium ion is characteristic of the ESI procedure and correlates with ion-molecule interactions under natural conditions. The presence of the peak of a cationized noncovalent complex of aspirin with phospholipid molecule, DPPC $\cdot$ ASP $\cdot \mathrm{Na}^{+}(m / z$ 936.5), proves the binding of aspirin to DPPH. It also testifies to the possibility of competition between aspirin and BQAC for the binding to the phospholipid molecular target.

Note that aspirin binds with a single DPPH molecule only. This contrasts with the features of binding

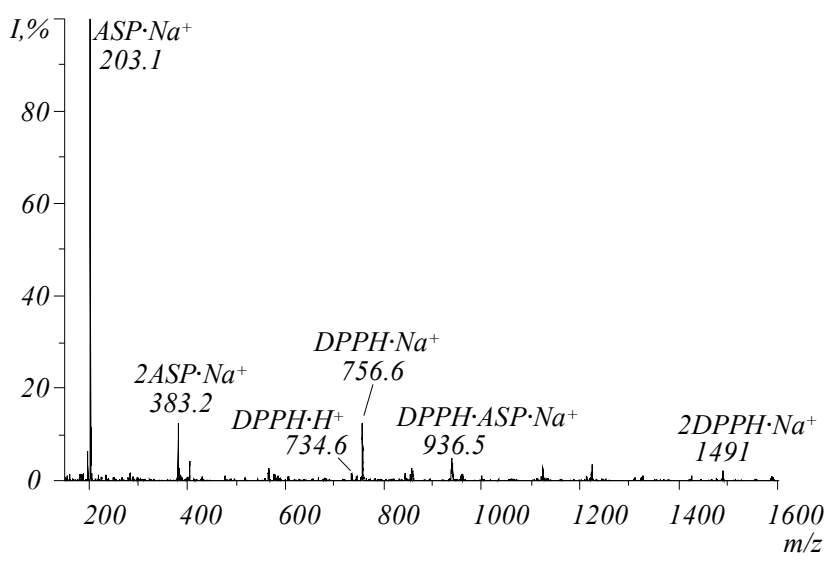

Fig. 1. ESI mass spectrum of a binary mixture of aspirin (ASP) and DPPH phospholipid in molar ratio 1:10

BQAC with DPPH in their binary mixtures, studied in our previous works $[10,12]$. It was found that the diction $\left(\mathrm{Cat}^{2+}\right)$ of BQAC can bind up to 9 DPPH molecules. Such supramolecular complexes, $n \mathrm{DPPH} \cdot \mathrm{Cat}^{2+}$, can be considered as a sufficient model of complexes BQAC with phospholipid membrane assemblies. Distinctions in the types of the complexes formed by aspirin and BQACs with DPPH are in correlation with the differences in mechanisms of their intermolecular interactions with phospholipids. While the dications of surface active BQACs are incorporated as components into phospholipid assemblies, the aspirin molecule, as it was shown in [15], interacts with the glycerol moiety of a separate DPPH molecule.

At the next stage of the study, ESI mass spectra of equimolar mixtures of BQACs and aspirin were examined (Fig. 2). The abundant peak of noncovalent associate of a BQAC dication and acetylsalicylic acid anion $\mathrm{Cat}^{2+} \cdot(\mathrm{ASP}-\mathrm{H})^{-}-$was observed at $m / z 801.6$ for decamethoxinum (Fig. 2, A), at $\mathrm{m} / \mathrm{z} 693.5$ for ethonium (Fig. 2, B), and at $m / z 753.6$ for thionium, along with the ions characteristic of individual components $\left(\mathrm{Cat}^{2+}\right.$ and $\mathrm{Cat}^{2+} \cdot \mathrm{Cl}^{-}$for BQACs, ASP $\cdot \mathrm{Na}^{+}$and $2 \mathrm{ASP} \cdot \mathrm{Na}^{+}$for ASP). This result pointed to one more possible mechanism of the BQAC-based drugs action modulation by aspirin, based on the formation of stable pair complexes between the BQAC dication and the organic acid anion, which deactivated the ionic forms of the medications. Note, that no definite information can be obtained as to a possibility of the formation of triple complexes $\mathrm{Cat}^{2+} \cdot 2(\mathrm{ASP}-\mathrm{H})^{-}$, since they are neutral and thus undetectable by mass spectrometry. 

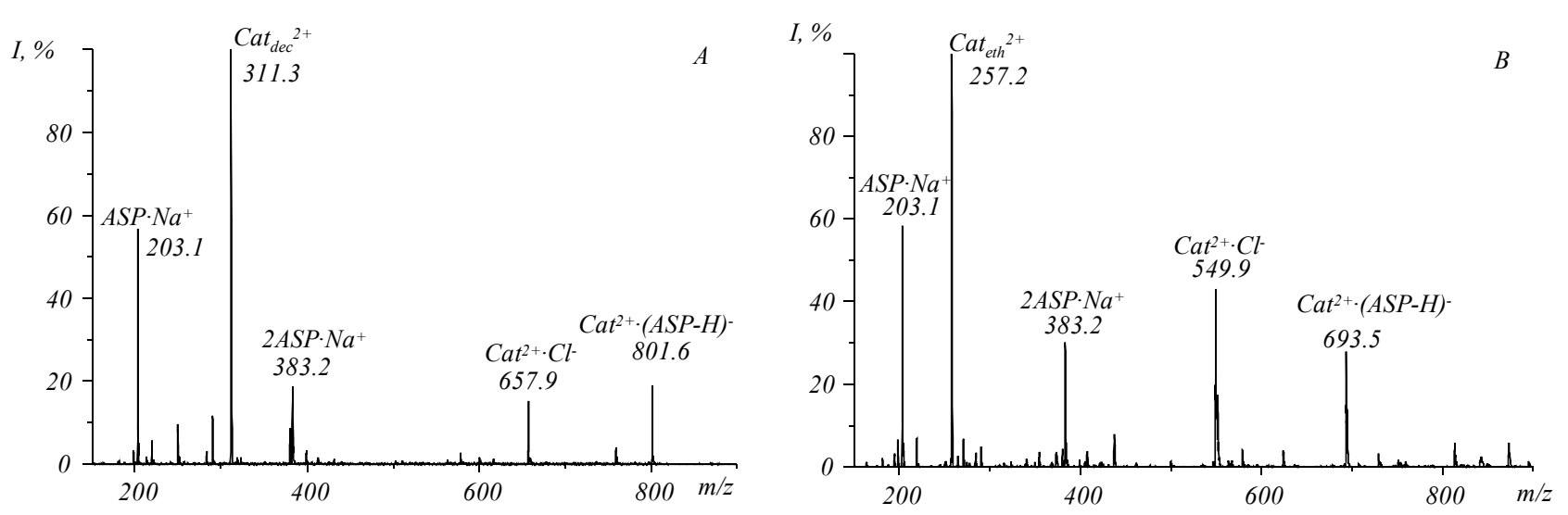

Fig. 2. ESI mass spectra of equimolar mixtures of decamethoxinum with aspirin $(A)$ and ethonium with aspirin $(B)$

Finally, the triple systems BQAC:ASP:DPPC (1:1:10 molar ratio) were probed (Fig. 3).

The intermolecular complexes recorded in the mass spectra reflected the complexity of specific noncovalent interactions in the model systems. Firstly, the supramolecular complexes of the BQAC dication with up to 4 DPPC molecules were formed similarly to the drugphospholipid associates in their binary systems $[10,12]$. Secondly, aspirin bound to a single DPPH molecule similarly to its behaviour in the binary system (Fig. 1). Thirdly, the dication-anion $\mathrm{Cat}^{2+} \cdot(\mathrm{ASP}-\mathrm{H})^{-}$complexes observed in the binary BQAC:ASP mixtures (Fig. 2) are formed in the triple system as well. The peaks distribution in the mass spectra pointed to the existence of a competition between BQACs and ASP for binding to DPPC molecules in the three systems, since abundances of the peaks of $n$ DPPC $\cdot \mathrm{Cat}^{2+}$ complexes, $\mathrm{Cat}^{2+}$. (ASP$\mathrm{H})^{-}$and DPPC $\cdot \mathrm{ASP} \cdot \mathrm{Na}^{+}$associates were of comparable intensities. The competition for binding ionic forms of the drugs to DPPH molecules and the formation of dication-anion complexes, revealed on the basis of mass spectrometric data, can be considered as molecular mechanisms of the possible drugs activity modulation.

The effects observed at the molecular level were further verified at the level of model biomembranes. To prove the incorporation of the membranotropic agents into DPPC membranes and to evaluate their combined effect, DSC measurements [13] were carried out along with the mass spectrometric experiments. The results of the DSC study of the binary BQAC:DPPC, ASP:DPPC and triple BQAC:ASP:DPPC systems have shown that doping of the hydrated DPPH bilayer by individual BQAC, aspirin [13] or gentinsic acid [11, 17] decreased the temperature of phase transition in the membrane, that evidenced the disordering effect in the membrane. At the same time simultaneous addition of both BQAC and acidic agents did not cause substantial membrane disordering, which was interpreted as a confirmation of deactivation (modulation) of the drugs action.

The effect of competitive intermolecular interactions observed at the level of biomolecules and model phospholipid biomembranes permits to formulate a task for further tests of the biological activity modulation for BQAC and acidic membranotropic agents as to their combined use at the level of microbial cells.

Conclusions. The results of the ESI mass spectrometric study demonstrate the competitive complexation in the model systems containing the BQAC, aspirin and membrane DPPH phospholipids. The observed phenomenon testifies to the possibility of modulation of the activity of membranotropic BQAC-based antimicrobial agents and aspirin under their combined usage via several scenarios: due to either the competition between these two types of drugs for binding to the target phospholipid molecules, or the formation of stable pair noncovalent complexes between BQAC and aspirin ions. Owing to these competitive complexations, the activity of the both agents at their combined use can be much lower than the activity of each single agent. Thus, the mechanisms of the possible drug activity modulation are demonstrated experimentally on the model molecular level systems.

The supposed modulation effect should be further inquired at the microbial cell level.

Acknowledgements. Authors acknowledge the Program of cooperation between Ukrainian and Hungarian 

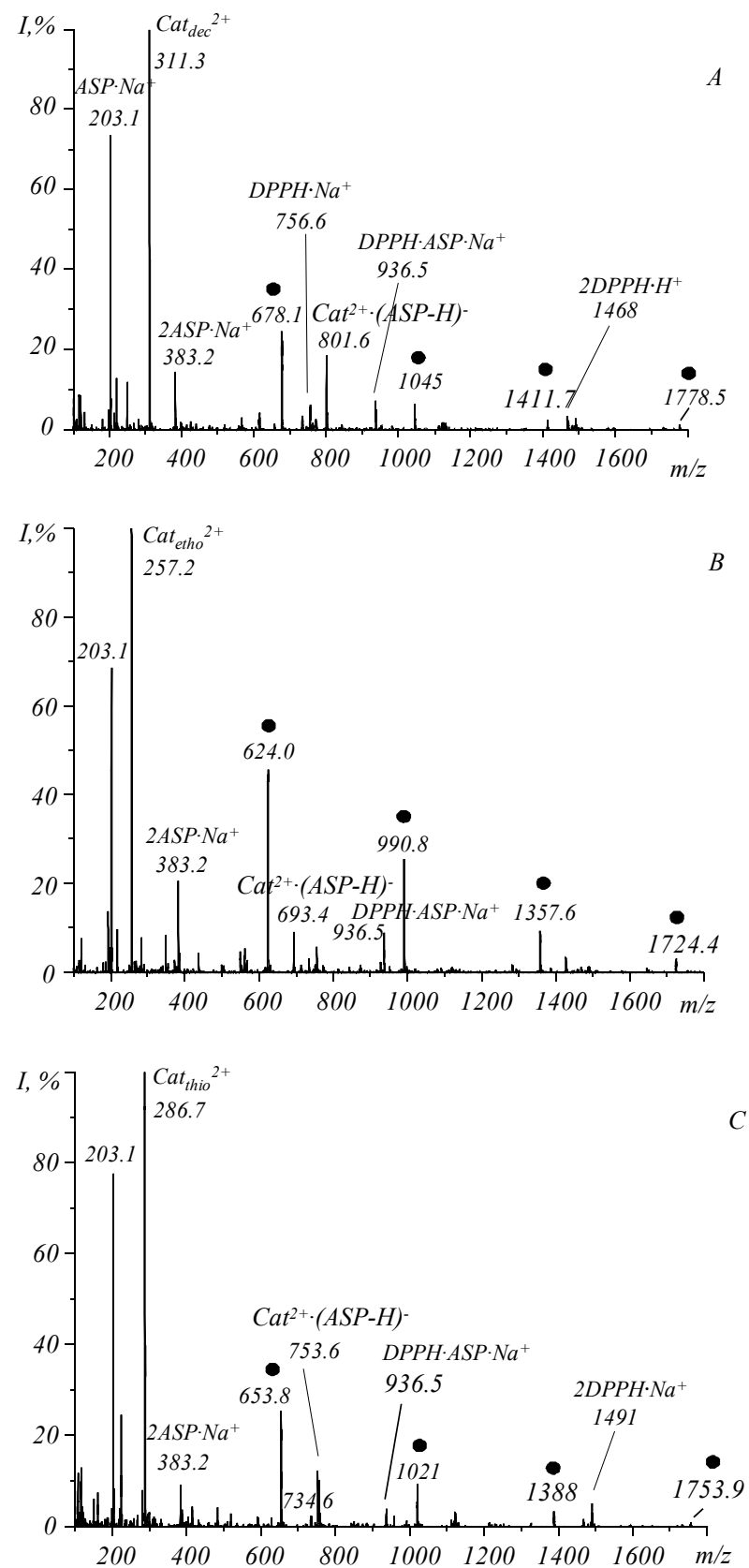

Fig. 3. ESI mass spectra of triple BQAC:ASP:DPPC systems: $A-$ $\mathrm{BQAC}$ is decamethoxinum; $B-\mathrm{BQAC}$ is ethonium; $C-\mathrm{BQAC}$ is thionium. Sets of peaks corresponding to $[\mathrm{Cat} \cdot n \mathrm{DPPC}]^{2+}$ complexes $(n=$ $=1 \div 4)$ are marked by $(\bullet)$ symbol

Academies of Sciences for the financial support of the visit to the Institute of Organic Chemistry of Research Centre for Natural Sciences of the Hungarian Academy of Sciences, where the experiments were carried out. Authors are grateful to Prof. L. N. Lisetski and Dr. O. V. Vashchenko for helpful discussion of the results.

\section{В. А. Пашинська, М. В. Косевич, А. Гоморі, К. Вєкей}

Модельне мас-спектрометричне дослідження конкурентної взаємодії мембранотропних антимікробних бісчетвертинних амонієвих препаратів і аспірину з мембранними фосфоліпідами

Резюме

Мета. Вивчення молекулярних механізмів можливої модуляції активності антимікробних бісчетвертинних амонієвих сполук (БЧАС) та аспірину (АСП) внаслідок формування нековалентних комплексів під час спільного введення препаратів двох типів у модельні системи з мембранними фосфоліпідами. Методи. Дво- $i$ трикомпонентні системи, які містять декаметоксин, етоній або тіоній, АСП і дипальмітоїлфосфатидилхолін (ДПФХ), досліджували методом мас-спектрометрії з іонізацією електроспреєм. Результати. Грунтуючись на даних аналізу асоиіатів, зареєстрованих у мас-спектрах, встановлено типи нековалентних комплексів, які формуються у досліджуваних системах, та обговорено їхню можсливу роль у модуляиії активності БЧАС і АСП. Утворення асоціатів дикатіонів БЧАС з аніоном АСП є одним з імовірних иляхів дезактивації іонних форм препаратів. Формування стабільних комплексів БЧАС з ДПФХ та АСП з ДПФХ у двокомпонентних системах, а також розподіл комплексів у трикомпонентних системах БЧАС:АСП:ДПФХ вказують на існування конкурениї̈ між препаратами двох типів за зв 'язування з ДПФХ. Висновки. Отримані результати свідчать про конкурентне комплексоутворення у модельних молекулярних системах, що містять БЧАС, АСП і мембранні фосфоліпіди. Виявлений факт підтверджує можсливість модуляиії активності бісчетвертинних амонієвих протимікробних агентів і аспірину при сумісному використанні завдяки конкурениії між ліками за зв'язування з мембранними фосфоліпідами, а також внаслідок формування стабільних нековалентних комплексів між БЧАС і АСП.

Ключові слова: конкурентне комплексоутворення, бісчетвертинні амонієві сполуки, аспірин, мембранні фосфоліпіди, масспектрометрія, іонізаиія електроспреєм.

\section{В. А. Пашинская, М. В. Косевич, А. Гомори, К. Векей}

Модельное масс-спектрометрическое исследование конкурентного взаимодействия антимикробных бисчетвертичных аммониевых препаратов и аспирина с мембранными фосфолипидами

Резюме

Цель. Изучение молекулярных механизмов возможной модуляции активности антимикробных бисчетвертичных аммониевых соединений (БЧАС) и аспирина (АСП) посредством формирования нековалентных комплексов при совместном введении препаратов двух типов в модельные системы с мембранными фосфолипидами. Методы. Двух- и трехкомпонентные системы, содержащие декаметоксин, этоний или тионий и АСП, а также дипальмитоилфосфатидилхолин (ДПФХ) исследовали методом масс-спектрометрии с ионизацией электроспреем. Результаты. На основании анализа ассоциатов, зарегистрированных в масс-спектрах, установлены типы нековалентных комплексов, образующихся в исследованных системах, а также обсуждена их предполагаемая роль в модуляции активности БЧАС и АСП. Формирование ассоииатов дикатионов БЧАС с анионом АСП является одним из возможных путей дезактивачии ионных форм препаратов. Образование стабильных комплексов БЧАС с ДПФХ и АСП с ДПФХ в 
двухкомпонентных системах, а также распределение комплексов в трехкомпонентных системах БЧАС:АСП:ДПФХ указывают на существование конкуренции между препаратами двух типов за связывание с ДПФХ. Выводы. Полученные результаты свидетельствуют о конкурентном комплексообразовании в модельных молекулярных системах, содержащих БЧАС, АСП и мембранные фосфолипиды. Обнаруженный факт подтверждает возможность модуляции активности бисчетвертичных аммониевых противомикробных агентов и аспирина при совместном применении вследствие конкуренции между лекарствами за связывание с мембранными фосфолипидами, а также благодаря формированию нековалентных комплексов между БЧАС и АСП.

Ключевые слова: конкурентное комплексообразование, бисчетвертичные аммониевые соединения, аспирин, мембранные фосфолипиды, масс-спектрометрия, ионизация электроспреем.

\section{REFERENCES}

1. Kaltashov I. A., Eyles S. J. Mass spectrometry in structural biology and biophysics: architecture, dynamics and interaction of biomolecules $/ 2^{\text {nd }}$ edition.-New York: John Wiley \& Sons, Inc., 2012.-312 p.

2. Siuzdak $G$. The expanding role of mass spectrometry in biotechnology. 2nd edition.-San Diego: MCC Press, 2006.-257 p.

3. Lebedev A. T., Artemenko K. A., Samgina T. Yu. Principles of mass spectrometry of proteins and peptides.-Moscow: Technosphera, 2012.-176 p. [in Russian].

4. Principles of mass spectrometry applied to biomolecules / Eds J. Laskin, C. Lifshitz.-New Jersey: John Wiley \& Sons, Inc., 2006.$687 \mathrm{p}$.

5. Electrospray and MALDI mass spectrometry: fundamentals, instrumentation, practicalities, and biological applications / Ed. R. B. Cole, $2^{\text {nd }}$ edition.-New Jersey: John Wiley \& Sons, Inc., 2010.-863 p.

6. Loo J. A. Electrospray ionization mass spectrometry: a technology for studying non-covalent macromolecular complexes // Int. J. Mass Spectrom.-2000.-200, N 1-3.-P. 175-186.

7. Wyttenbach Th., Bowers M. T. Intermolecular interactions in biomolecular systems examined by mass spectrometry // Annu. Rev. Phys. Chem.-2007.-58.-P. 511-533.

8. McCullough B. J., Gaskell S. J. Using electrospray ionisation mass spectrometry to study non-covalent interactions // Comb. Chem. High Throughput Screen.-2009.-12, N 2.-P. 203-211.

9. Pashinskaya V. A., Kosevich M. V., Gomory A., Vashchenko O. $V$., Lisetski L. N. Mechanistic investigation of the interaction between bisquaternary antimicrobial agents and phopholipids by liquid secondary ion mass spectrometry and differential scanning calorimetry // Rapid Commun. Mass Spectrom.-2002.-16, N 18.-P. 1706-1713.

10. Pashynska V. A., Kosevich M. V., Van den Heuvel H., Cuyckens $F$., Claeys $M$. Study of non-covalent complexes formation between the bisquaternary ammonium antimicrobial agent decamethoxinum and membrane phospholipids by electrospray ionization and collision-induced dissociation mass spectrometry // Vistnyk Karazin National University. Biophys. Bull.-2004.637, N 1-2 (14).-P.123-130.

11. Vashchenko O., Pashynska V., Kosevich M., Panikarska V., Lisetski $L$. Lyotropic mesophase of hydrated phospholipids as model medium for studies of antimicrobial agents activity // Mol. Cryst. Liq. Cryst.-2011.-547, N 1.-P. 155-163.

12. Pashynska V. A., Kosevich M. V., Gomory A., Vekey K. Investigation of formation of noncovalent complexes between antimicrobial agent ethonium with membrane phospholipids by electrospray ionization mass spectrometry // Mass-Spectrometria.2012.-9, N 2.-P. 121-128.

13. Vashenko O. V., Kasian N. A., Pashynska V. A., Kosevich M. V., Ermak Yu. L., Lisetskyi L. N. Lipid membranes as a model medium for solution of the applied biomedical problems // Functional materials for scintillation technology and biomedicine.Kharkiv: ISMA, 2012.-428 p. [in Russian].

14. Pokrovsky V. A., Kosevich M. V., Osaulenko V. L., Chagovets V. V., Pashynska V. A., Shelkovsky V. S., Karachevtsev V. A., Naumov $A$. Yu. Matrix assisted laser desorption-ionization study of bisquaternary ammonium antimicrobial agent decamethoxinum in 2,5-dixydroxybenzoic acid // Mass-Spectrometria.-2005.-2, N 3.P. 183-192.

15. Panicker L., Sharma V. K., Datta G, Deniz K. U., Parvathanathan P. S., Ramanathan K. V., Khetrapal C. L. Interaction of aspirin with DPPC in the lyotropic, DPPC-Aspirin-H2O/D2O membrane// Mol. Cryst. Liq. Cryst.-1995.-260, N 1.-P. 611-621.

16. Guevremont R., Siu K. W. M., Le Blanc J. C. Y., Berman S. S. Are the electrospray mass spectra of proteins related to their aqueous solution chemistry? // J. Am. Soc. Mass Spectrom.-1992.-3, N 3.-P. 216-224.

17. Vashenko O. V., Pashynska V. A., Kosevich M. V., Boryak O. A., Kasian N. A., Lisetski L. N. Investigation on combined effect of quaternary ammonium compounds and an organic acid on model phospholipid membranes // Biophys. Bull.-2010.-25, N 2.-P. 55-72. 